\title{
Northwestern Russia and the federative system
}

This chapter gives a presentation of Russia's federative system and of the political and economic situation in the northwestern regions of the country. The objective of the first part of the chapter is to describe the overarching political structures of the Russian Federation, particularly those pertaining to the centre-region dimension, thus providing a backdrop to the discussion of various agencies' involvement in the implementation of international environmental agreements. The second part of the chapter addresses the particular political and economic conditions under which implementation is supposed to take place in the case studies of the book.

\section{The development of a Russian federation}

The Russian Federation, in the form it has taken since the disintegration of the Soviet Union, is the direct successor of the Russian Soviet Federative Socialist Republic (RSFSR). Some central traits of this structure, particularly those concerning the formal arrangements of centre-periphery relations, have been retained in the new federation. However, the substance of these relations has undergone considerable changes since the Soviet era. After a brief outline of the Soviet legacy, the main features of the new Russian federalism, focusing on legal, political and economic aspects, will be presented in this section.

\section{Federalism and regional self-government: the Soviet legacy ${ }^{1}$}

Unlike its predecessor, the Russian empire, the Soviet Union was organised in a federal structure. ${ }^{2}$ Originally, the rationale for establishing a federal state structure was partly tactical, partly a 
consequence of Bolshevik nationalist theory. From a tactical point of view, the organisation of the RSFSR as a federal unit in January $1918,{ }^{3}$ as well as the establishment of the Soviet Union four years later, can be regarded as a historical compromise between the Russian-dominated Bolshevik party and their non-Russian allies (Smith 1995). The Bolsheviks were facing pressures from civil war and dissolution tendencies within the previous empire, and the most important ethno-national groups were granted a certain degree of autonomy as a reward for signing up to the new federal state formation. Furthermore, the establishment of a federal structure partly follows from the prescriptions of Marxist ideology. Marx himself had characterised the Russian empire as the 'prison of nations', and his statement that 'no nation is free as long as it suppresses another nation' was frequently cited by Lenin (Kaiser 1994).

The Soviet federal structure that evolved under Stalin was a compromise between these ideological guidelines and the demands of practical politics. The result was a form of 'pro forma ethno-federalism organised according to the matryoshka principle' (Blakkisrud 1997, p. 13). Ethnic groups of more than one million people, living within a geographical region that could easily be demarcated, whose territory bordered on a third state, were allowed to create union republics. Groups failing to meet one or more of these requirements were granted a more limited autonomy within the borders of the union republics. Depending on various conditions, such as the size of the population and its level of development, these groups could establish autonomous republics, autonomous oblasts (regions) or autonomous okrugs (districts). The administrative division of the union was subject to frequent revisions under Stalin, and to a certain degree also under Khrushchev, but from the early 1960s to 1991, it consisted of 15 union republics, 20 autonomous republics, 8 autonomous oblasts and 10 autonomous okrugs.

Parallel to the ethno-federal structure, there existed a strictly administrative-territorial division in krays (territories) and oblasts within the greater union republics. These territorially defined units were directly subordinate to the union republics and were thus not part of the federal structure. On the other hand, krays and oblasts could themselves contain federal units, as an autonomous oblast could be included in a kray, and an autonomous okrug in either a kray or an oblast.

Despite the formal arrangement of both the Soviet Union and the RSFSR as federations, their power structure was extremely 
hierarchical and centralised. ${ }^{4}$ In effect, a total subjection to central party organs was required. The Soviet system of government consisted of three parallel hierarchies: the representative or legislative organs (soviets); the executive organs (which were nominally subordinate to the soviets at each level); and the Communist Party of the Soviet Union (CPSU). At each administrative level (union, republic, oblast, okrug etc.), there was a soviet, an executive committee and a party organisation. ${ }^{5}$ The party provided the vertical line of command that held the system together. The soviets were large, 'decorative' assemblies that met rarely, and did little more than rubber-stamp the decisions of the executive committees, which had usually been agreed with the party organisation at the relevant level. The soviets, on their part, worked according to the paradoxical principle of democratic centralism: deputies at each level were accountable both to their electorate and to the soviet at the next level up. In practice, however, centralism generally had the upper hand, and, as already described, party organs exercised a complete control over decisions in soviets and executive committees.

\section{From RSFSR to the Russian Federation}

Among the most dramatic results of Gorbachev's reforms was the nationalistic awakening that eventually led to the dismantling of the Soviet Union itself. After the 1991 August coup attempt failed, the very processes that the coup makers tried to prevent started to accelerate. Gorbachev's authority became even weaker than before the failed coup, and institutions at the union level lost most of their legitimacy, influence and, eventually, also financing. By December 1991, the actual decision-making authority in the Soviet Union had been transferred to the republic level. One republic after another declared itself sovereign, and when the leaders of the RSFSR, Ukraine and Belarus met in early December to create the Commonwealth of Independent States (CIS), the demise of the Soviet Union was formalised.

There seems to have been no disagreement among Russian leaders that a federal structure should be retained also in the new Russian state formation. There were, however, different opinions as to which form of federalism should be chosen. ${ }^{6}$ The outcome of the debate was quite pragmatic: in the unstable political situation of the day, extensive administrative reforms were perceived as too hazardous, and it was agreed to preserve a slightly modified version of 
the old structure. The system of both ethnically and territorially defined federal subjects was retained. The latter were kept unchanged, while there was an upgrading in administrative status of the autonomous republics and four of the five autonomous oblasts, which were hereafter defined as republics. ${ }^{7}$ The new Russian Federation consists of 89 federal subjects, of which 32 are ethnically defined (21 republics, 1 autonomous oblast and 10 autonomous okrugs) and 57 are territorially defined (6 krays, 49 oblasts and 2 cities with status as federal subjects). The federal subjects vary widely with respect to both population and territory. Whereas the autonomous areas comprise more than 50 per cent of the federation's territory, they contain only 18 per cent of its population.

The most controversial issue of Russian politics during the years 1992-93 was the elaboration of a new federal constitution. The primary controversy ran along the basic fault lines in Russian politics: the division of power between the President and the Parliament, and between federal authorities and the regions. The process of elaborating a new constitution was embarked upon already in 1990, but it was only with the dissolution of the Soviet Union and the establishment of the Russian Federation that the need for a new basic legal framework became urgent. Various drafts were presented during 1992 and the first half of 1993. Two of these became the object of serious discussion, one produced by President Yeltsin and one by the Constitutional Committee. As was to be expected, the President's proposal prescribed a strong presidential rule, while that of the Constitutional Committee implied a parliamentarian model. The federal subjects diverged in their view of the proposals. The vertical division of power, i.e. the federal structure, was more important to them than the horizontal organisation of the state. As the controversy sharpened, both the President and the Parliament made new concessions to the regions in an attempt to win their support. Several aspects of President Yeltsin's proposal are clearly designed to suit the interests of the ethnically defined federal subjects.

In June 1993, Yeltsin summoned a constitutional conference, which one month later launched a compromise between the two proposals. A working group was appointed in September to implement further co-ordination, but before it could present its result, political realities in Russia changed dramatically. On 21 September, Yeltsin dissolved the Parliament and ordered new elections. Fierce protests from the opposition immediately followed. The dispute 
culminated on 3 and 4 October when the protests of the parliamentarians and their supporters, who had barricaded themselves within the White House, were overcome by force. After these incidents, President Yeltsin had control of the parliamentary opposition, and his revised constitution draft represents a clear concentration of power with the presidential apparatus, as well as a centralist structure of decision-making.

As the Parliament was now eradicated as a political competitor, the President no longer depended on the same level of support from the federal subjects as before. Several of the privileges they had won in the course of the previous power struggle were now modified or even omitted from the constitution draft. The republics were, for instance, no longer described as sovereign entities. When the draft was voted on in a referendum on 12 December, more than half of the republics as well as 11 territorially defined federal subjects rejected it, either through low participation or by votes against it from more than 50 per cent of the electorate. Nevertheless, the new Constitution was adopted since it received support from 58.4 per cent of the electorate at the federal level, and since election turnout was above 50 per cent (54.8 per cent).

\section{Evolving centre-region relations}

The 1993 Constitution replaced the centralised administrative regime of the Soviet period with a system that grants the federal subjects a considerable degree of legal autonomy. Executive power of the regions is nested with the regional administration and its head of administration, or governor (in the republics: president). The large regional soviets (with 200-250 members) are replaced by smaller legislative bodies - most often named dumas ${ }^{8}-$ at the regional level.

This section provides a brief overview of main aspects of the legal relationship between Moscow and the subjects of the Russian Federation. It also raises the question whether the formal rights of the federal subjects have been followed up in practice. First, have political realities in post-Soviet Russia allowed the devolution of power to ensue according to the legal stipulations of the Constitution? Second, has decentralisation been accompanied by sufficient sources of economic revenue at the regional level or been reduced to a judicial and/or political exercise of good intentions? 
Legal aspects ${ }^{9}$ The Constitution lays down a threefold framework for the distribution of jurisdiction between federal and regional authorities (see Figure 3.1). Article 71 lists all areas where federal authorities have exclusive competence, including foreign and security politics. Article 72 defines a comprehensive list of areas over which federal and regional authorities have joint jurisdiction. Article 73 states that except for the areas of jurisdiction mentioned in Articles 71 and 72 the federal subjects 'exercise the entire spectrum of state power'. The picture is completed by Article 76, Paragraph 4, which states that on matters of joint jurisdiction 'laws and other regulatory legal acts of the subjects of the Russian Federation may not contravene federal laws'.

In a discussion of centre-region relations, Article 72 is clearly of most interest since it involves both the federal and regional level. The Article lists 14 different areas in which the two levels share jurisdiction, among them 'issues of possession, use and management of the land, mineral resources, water and other natural resources' (Article 72, Paragraph 1(c)) and 'management of natural resources, protection of the environment and ecological safety' (Article 72, Paragraph 1(e)). In accordance with Article 76, Paragraph 5, the Constitution grants federal legislation priority over regional legislation in areas of joint jurisdiction. On the other hand, the scope of regional legislation is not limited by the areas covered by federal legislation. In practice, the federal legislature has so far failed to pass legislation on a variety of important issues under Article 72, leaving considerable room for regional legislators to freely draft regulations. ${ }^{10}$

In addition to working through the above-mentioned regional legal initiative, some federal subjects have tried to reduce the impact

Figure 3.1 The legal hierarchy for distribution of competence between the federal and regional levels

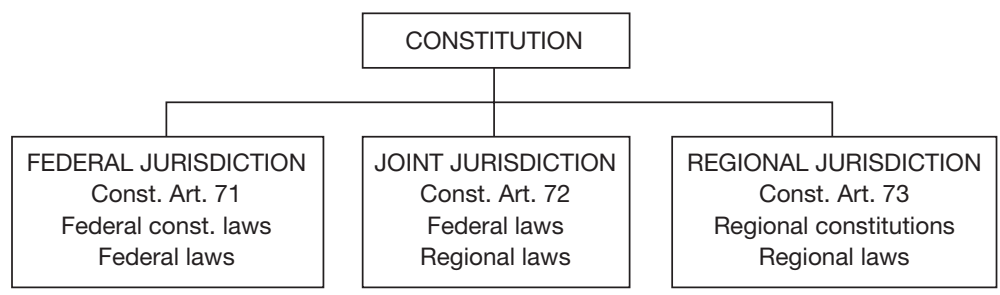

Source: Risnes (2001). 
of the legislative vacuum by concluding bilateral agreements with the federal centre. These agreements normally contain declaratory provisions on co-operation between federal and regional authorities, but are followed by a number of sub-agreements regulating more practical questions of particular importance to the federal subject in question. Although initially conceived as a way to bring a reluctant Republic of Tatarstan back into the Federation, the bilateral treaties soon developed into a dynamic tool for regulating centre-region relations. By now, more than half of the federal subjects have adopted such agreements. On the one hand, the adoption of bilateral agreements strengthens the legal basis of centre-region relations; on the other, they increase the diversity and inconsistency of the legal system as a whole.

Finally, it should be noted that the centralised administrative structure of the Soviet period has not disappeared altogether. Compared to the significant changes in Russian law and politics since the early 1990s, the bureaucracy has changed surprisingly little. Most important spheres of politics are still the exclusive responsibility of federal authorities - ministries (23) ${ }^{11}$ state committees (6), federal commissions (2), federal services (13), federal agencies (8) and supervisory agencies (2) - and these have a fine-meshed net of representations in the regions. The new legal status of regional authorities resulted in a need for co-operation between regional administrations and regional branches of federal authorities. The cooperation was often co-ordinated by the presidential representative in the region, a position introduced by President Yeltsin to oversee the implementation in the regions of decisions made at the federal level. ${ }^{12}$ In general, the presence of federal authorities in the regions appears to have constituted a buffer against effective transferral of power to the federal subjects. On the other hand, it has been claimed that regional authorities in reality have enjoyed considerable influence over federal administration in the regions. As a result, President Putin in May 2000 introduced seven new federal administrative districts aimed at managing the work of federal agencies in the regions (see next section). At the same time, he took an initiative to bring all regional legislation into accordance with federal legislation and review the future of the bilateral agreements by the end of 2001 .

Political aspects ${ }^{13} \quad$ The years prior to the adoption of the 1993 Constitution had been characterised by demands for increased sovereignty 
for political entities at all levels in the Soviet Union/Russian Federation, often referred to as the 'Parade of Sovereignties'. ${ }^{14}$ As noted above, however, President Yeltsin no longer depended on the strong support of the regions after defeating the Supreme Soviet in the autumn of 1993. Already before that, he had secured for himself the right to personally appoint the heads of regional administrations (governors) although the Parliament - against the veto of the President - in the spring of 1991 had adopted a law which opened for direct election of heads of administration. ${ }^{15}$ Combined with the introduction of presidential representatives in the regions (see previous section), the period 1993-96 is clearly characterised by Yeltsin tightening his grip on regional executives. ${ }^{16}$ Moreover, the division of power emerging during this period developed along what has been called the 'executive vertical', replacing the Communist Party as the 'transmission belt' in relations between the regions and political centre of the state. At both the federal and regional level, the legislatures were considered subordinate political positions.

After 1996, the Russian regions have consolidated their position and to some extent also increased their autonomy. A major event in centre-region relations was the long awaited gubernatorial elections organised during the winter of 1996-97 (the 'Parade of Governors'). The heads of the regional administrations can now refer to a popular mandate rather than presidential decree as their source of legitimacy, clearly reducing their dependence on federal authorities. The centre can no longer rely on direct control over the executive vertical and has now to resort mainly to the budgetary process in its efforts to influence development in the regions (see next section).

Recent years have again been characterised by federal authorities attempting to stop the devolution of power from the centre. As mentioned above, giving the presidential representatives responsibility for overseeing the activities of federal agencies in the regions was no guarantee of these representatives' loyalty to federal authorities. In practice, the majority of presidential representatives appear to have 'gone native', ending up as allies of the governors or republican presidents. In the May 2000 reorganisation mentioned above, President Putin introduced a new administrative layer between the centre and the federal subjects, the federal okrugs. Seven federal okrugs were established, led by presidential representatives. The old system of presidential representatives in the federal subjects was abolished. It can be argued that the reorganisation represents a re-centralisation 
in itself. Simultaneously, the regional leaders lost the control they had acquired over federal agencies located on their territory. Shortly after, Putin also curbed the legal power of the regional heads of administration by depriving them of their representation in the Federation Council, the upper house of the Federal Parliament.

Economic aspects ${ }^{17}$ In the period that followed the establishment of the Russian Federation, the economy of the country underwent radical economic reforms. The main elements were privatisation, price and tax liberalisation and the adoption of a number of laws to facilitate the introduction of a market economy. The economic aspect of Russian federalism rests on three main pillars: the division of responsibility between federal, regional and local authorities; the re-distributive effects of the tax system; and transfers between the federal and regional level. The division of responsibility between the different levels of government implies that the federal level is responsible for macro-economic stabilisation, inter-regional distribution and the provision of public goods of national interest, such as defence. Sub-regional authorities cover expenditures such as health, primary education and housing subsidies. ${ }^{18}$ The Russian tax system consists of local, regional and federal taxes. The most important taxes are the VAT, the corporate profit tax and the personal income tax. ${ }^{19}$ Eighty-five per cent, 81 per cent and 3 per cent, respectively, of these taxes is transferred to the federal budget. The tax system is generally considered to be complicated, and compliance is low. Transfers from federal authorities to the regions is the third instrument of fiscal federalism in Russia, constituting approximately 10-12 per cent of the total federal budget in recent years. ${ }^{20} \mathrm{~A}$. McAuley (1997) ${ }^{21}$ finds that more support is transferred to regions that are poorer than the national average compared to other regions. Moreover, ethnically defined federal subjects are, almost without exception, net receivers of federal support.

Until the eve of the rouble crisis in August 1998, the Russian economy seemed to have stabilised and even embarked on a slightly positive trend. During the crisis - by Russians referred to only as August - Russia changed its exchange rate regime from a fixed exchange rate to a floating one. The devaluation was regarded as a major defeat for the Russian stabilisation policy, ${ }^{22}$ but in hindsight it appears to have implied one step back in order later to take two steps forward. The rouble has stabilised, inflation did not accelerate, the trade balance 
has improved, and, most importantly, Russia had economic growth in 1999 and 2000.

Under the Soviet central planning system, political priorities, and not market mechanisms, determined which resources should be developed and where production should take place. The extremely centralised decision-making process, low perceived transportation costs and remote sources of raw materials contributed to a decentralised economic geography. A by-product of Soviet resource exploitation and industrial policy was the construction of a large number of mono-industrial towns in the resource-rich, formerly largely unpopulated northern peripheries of the Soviet Union.

During the Soviet period, the centripetal forces that have depopulated Western peripheral regions were not in operation in Russia. Paradoxically, the introduction of decentralised economic decisionmaking may reactivate these centripetal forces. Exposed to new demands for profitability and competitiveness, the transport-intensive Soviet-style economy faces severe structural problems. Depopulation may spark a negative spiral at the regional level: fewer people means a decreasing home market for local industries. This has two implications for a region's industrial potential. First, it reduces the market for local supply industries. Second, it reduces the incentives for the location of other industries to the region. Ironically, then, economic decentralisation in a post-Soviet Russian context thus might lead to depopulation and centralisation.

\section{The economy and politics of Northwestern Russia}

This section presents the northwestern periphery of the Russian Federation, providing an overview of the economic situation in the region and its most important political power structures. First, the geographical concept 'Northwestern Russia' is discussed and defined for further use in the book. Next, a brief historical background is provided along with some main characteristics of the region in terms of population, resources and industry. Finally, an overview is provided of the political system at the regional level in Northwestern Russia.

\section{Northwestern Russia: a concept definition}

In Russia, there are several 'official' definitions of the country's northwestern part. The Russian Northwestern Economic Region, for instance, is defined as the oblasts of Novgorod, Leningrad and 
Pskov as well as the city of St Petersburg; whereas Murmansk, Arkhangelsk and Vologda Oblasts, the Republics of Karelia and Komi and Nenets Autonomous Okrug are defined as the Northern Economic Region..$^{23}$ The Northwestern Association, on its part, was established early in 1993 to facilitate co-ordination of the northern regions' relations with the federal centre and to draw Moscow's attention to its particular problems. ${ }^{24}$ It includes the Republics of Karelia and Komi, as well as Arkhangelsk, Vologda, Kaliningrad, Kirov, Leningrad, Murmansk, Novgorod and Pskov Oblasts, Nenets Autonomous Okrug and the city of St Petersburg.

The Russian conceptions of 'Northwestern Russia' are all either significantly broader than - or totally different from - those found in the West, in particular in the Nordic countries. In the West, the term 'Northwestern Russia' is normally used when referring to the Russian part of the Barents Euro-Arctic Region, i.e. Murmansk and Arkhangelsk Oblasts, the Republic of Karelia and Nenets Autonomous Okrug. However, there is a tendency at least in Norway to understand the term even more narrowly; people occasionally speak of Northwestern Russia even if they primarily have in mind the Kola Peninsula or Murmansk Oblast. In this book, the subject matter of the discussion forces a compromise between the two latter definitions. In terms of implementation of international environmental agreements in the Barents Sea region, Murmansk and Arkhangelsk Oblasts, and, partly, also the Nenets Autonomous Okrug, are by far the most relevant federal subjects. Among these, focus is in particular on the former. For instance, although the 'northern fishery basin' of the Russian Federation is defined as including the fisheries of Murmansk and Arkhangelsk Oblasts, the Republic of Karelia and Nenets Autonomous Okrug, the majority of fishing enterprises are located in Murmansk Oblast. ${ }^{25}$ Likewise, air pollution control is more urgently required on the Kola Peninsula than in the rest of the region, as are nuclear safety measures.

\section{A brief historical background}

Northwestern Russia represents a true microcosm of Soviet and Russian administrative-territorial engineering. The four federal subjects that are normally understood of as comprising 'Northwestern Russia' include the three main categories of Russian federal entities: Karelia is a republic, Nenets an autonomous okrug, and Arkhangelsk and Murmansk are oblasts. ${ }^{26}$ A brief historical background to the 
two latter regions, covering the main geographical scope of the current study, is given in the following.

The history of Murmansk (see Figure 3.2) - both the administrative entity and the city itself - is a relatively short one. In the autumn of 1997, the inhabitants of Murmansk City celebrated the 80th anniversary of its founding. At the same time, those so inclined could celebrate the 80th anniversary of the Bolshevik Revolution, underscoring the relatively brief political and economic history of the region.

Figure 3.2 Murmansk Oblast

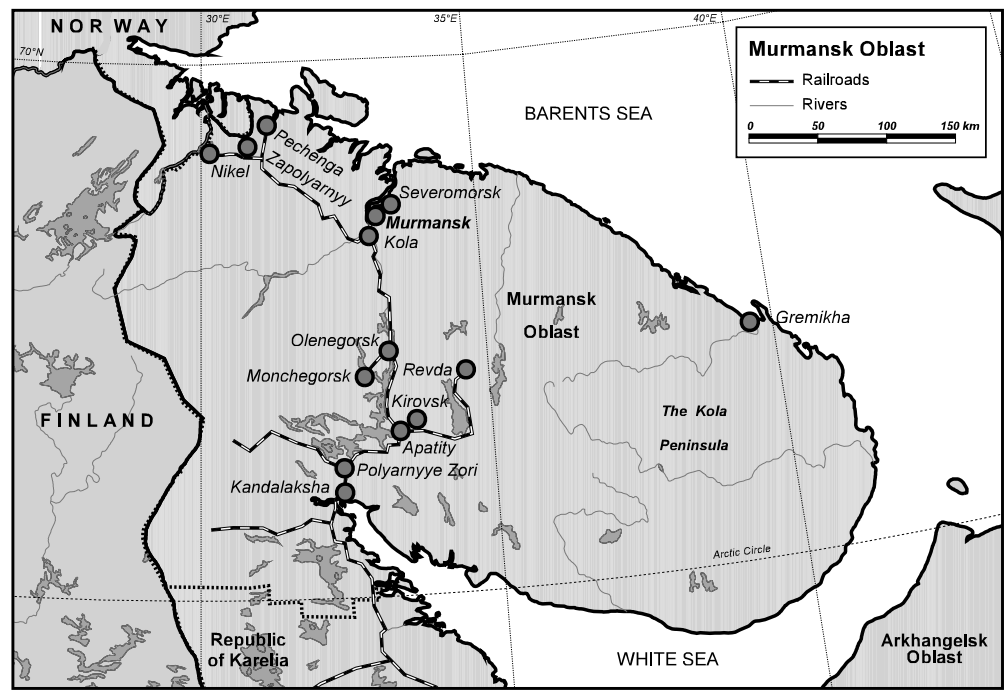

Until World War I, the vast territory of the Kola Peninsula was inhabited by only a few thousand people and was of practically no significance, military or otherwise, to the Russian empire. ${ }^{27}$ Although the strategic potential of the ice-free Murman Coast had been recognised at least a half-century earlier, the Russian authorities did not move to develop this potential until they were forced to act by the vicissitudes of World War I. The lack of ice-free ports in European Russia, except for those in the Black and Baltic Seas where the Russian fleets could easily be cut off in narrow straits, prompted the construction of the Murman Railway, which reached the Kola 
Fjord in 1916. The same year, the supply port Romanov-naMurmane was founded at the end-stop of the railway line. In 1917, its name was changed to Murmansk.

During the Civil War of 1918-20, Murmansk was a base for British, French and American expeditionary forces against the Bolsheviks, and Soviet power was established only in 1920. The following year, Murmansk became the administrative centre of the newly formed Murmansk Guberniya. From 1927 through 1937, the region was administered as an okrug within Leningrad Oblast. As a result of the region's growing population and economic and political significance, Murmansk attained oblast status in 1938. ${ }^{28}$

During World War II, the strategic importance of Murmansk and the Kola Peninsula was proved again - both as a vital corridor for supplies during the siege of Leningrad and as the home base for the Northern Fleet, which had been founded in 1933. During the subsequent Cold War, Murmansk Oblast was one of the two regions within the Soviet Union that shared borders directly with a NATO member and was thus given high priority. The peninsula was heavily militarised, and by 1970 the Northern Fleet had become the largest and most important of the Soviet naval fleets. The military complex employed a significant part of the population and developed into a state within the state, endowed with its own infrastructure, generally superior to the civilian one.

The civilian sector of the post-war economy in the oblast came to be dominated by heavy industry. Entire towns and cities were built from scratch around enormous mining, metallurgical, and chemical enterprises (e.g. Nikel, Monchegorsk, Apatity and Kirovsk). Many of these industrial centres were constructed along the Murman Railway, ${ }^{29}$ which still constitutes the infrastructural backbone of the Kola Peninsula. In coastal settlements, and especially in Murmansk City, the fisheries and fish processing industry also played a significant role. The fish processing industry in Murmansk gradually came to supply the USSR as a whole.

Murmansk is a typical Russian northern region in the sense that major population growth post-dated the Bolshevik Revolution and was based on the construction of a relatively small number of massive industrial enterprises and military complexes. The industrialisation policies of the 1920s ushered in a period of mass immigration to the Kola Peninsula, a trend that except for a temporary slump during World War II continued until 1991. The immigrants were 
attracted by a number of advantages granted to the inhabitants of the Soviet North, such as higher wages, a lower retirement age, and subsidised holidays at resorts at the Black Sea. Although the standard of living in Murmansk Oblast therefore was well above the Soviet average, many of its inhabitants still regarded it as a temporary place of residence rather than as their permanent home. Most workers returned to their former areas of residence upon retirement, if not before, to live on their generous pensions and the savings that the northern system of compensation had allowed them to accumulate. Those working in the military and fisheries sectors, where personnel turnover is generally high, had an even weaker sense of attachment to the region. The region's demographic profile has reflected this situation; the average age of the population was low, and young males were over-represented.

The two oblasts of the northwestern Russian periphery, Arkhangelsk and Murmansk, represent old and new Russia, respectively. Whereas Murmansk is a prime example of the Soviet industrial and military adventure, Arkhangelsk (see Figure 3.3) is a centre of traditional Russian cultural heritage. Zavolochya, which is the old name of the region where Arkhangelsk Oblast is now situated, was colonised by the Novgorodians in the Middle Ages. With the fall of Novgorod, the territories along the shores of the White Sea came under Moscow's control. The population was sparse, and settlement spearheaded by hermits and monks. At the site where Arkhangelsk City is located, the Monastery of Michael the Archangel was founded in 1136, and there were also a number of other important monasteries in the region, e.g. on the Solovets Islands.

The original administrative centre of the region was the city of Kholmogory, which in the late sixteenth century, at the time Arkhangelsk City was founded, had some 1,000 inhabitants. The immediate reason for the founding of Arkhangelsk was Russia's loss of the Baltic port of Narva in 1581, which cut Moscow's access to the Baltic Sea. Some thirty years earlier, the English seaman Richard Chancellor, in a failed attempt to find a northeast passage to China, had landed in the White Sea. Chancellor was received in Moscow by Tsar Ivan IV, who granted England favourable conditions for trade with Russia over the White Sea. Commerce developed rapidly, and after the loss of Narva Ivan the Terrible in 1584 decided to develop a new port to facilitate this trade at the shore of Northern Dvina, i.e. Arkhangelsk. 
Figure 3.3 Arkhangelsk Oblast and Nenets Autonomous Okrug

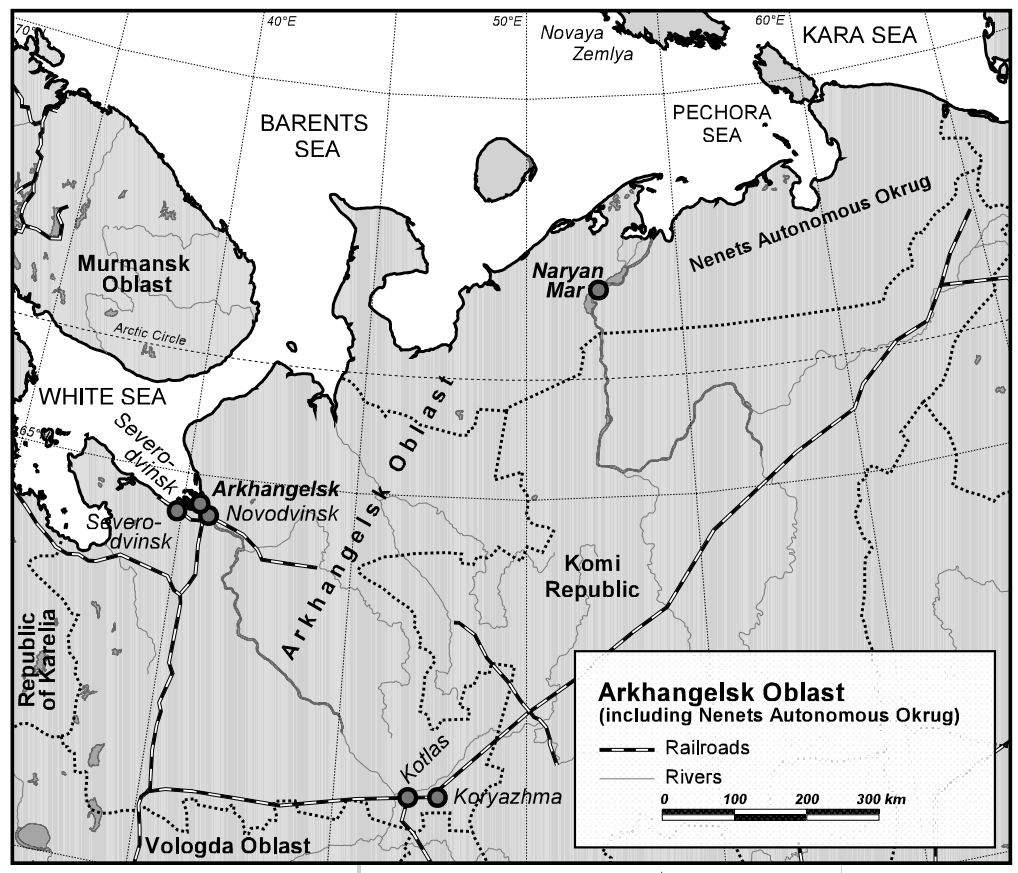

The new city soon became an important harbour for trade in grain, furs, leather, lard and wax. In 1693, the first state-run shipyard in Russia was established in Arkhangelsk - what has later been commemorated as the founding of the Russian navy. After Peter the Great opened his 'Window on Europe', St Petersburg, in 1703, however, exorbitant duties were introduced to redirect trade to this new town, and Arkhangelsk lost some of its importance. In 1708, Arkhangelsk Guberniya was founded. The guberniya was considerably larger than the present oblast, covering the Russian European North from the Danish-Norwegian border to the Urals. Although trade dwindled, Arkhangelsk remained by far the largest city in the Russian north. Moreover, the building of a railway from Moscow to Arkhangelsk in 1898 spurred industrial growth in the region.

In the Civil War that followed the October Revolution of 1917, Arkhangelsk became a centre of resistance against the Bolsheviks and headquarters of the White Army under General Miller's command. 
In August 1918, British troops landed in the city, and although they were withdrawn in 1919, Arkhangelsk did not fall into Soviet hands until the following year. The Soviet development of the Far North led to new growth in Arkhangelsk. While the population of Arkhangelsk City was 45,000 at the end of the Civil War, it quadrupled over the next decade and peaked at over 425,000 at the end of the Soviet period. Soviet focus on industrialisation and urbanisation led not only to an increased share of urban population (from 39.6 per cent in 1939 to 73.4 per cent in 1989) but also to a fall in rural population in absolute numbers (from 641,800 in 1939 to 417,800 in 1989). Overall, the population of the oblast increased by almost half a million from 1,062,600 in 1939 to 1,515,800 in 1989.

In 1929, Soviet authorities established the Northern Kray, the administrative centre of which was Arkhangelsk City. In 1937, the kray was dissolved and replaced by two oblasts, Arkhangelsk and Vologda. Nenets Autonomous Okrug remained a constituent part of the oblast throughout the Soviet period. It is a subject of the Russian Federation, but still forms part of Arkhangelsk Oblast. Although the 1993 Constitution recognises all subjects of the federation as equal in relation to the federal centre, it maintains the system of autonomous districts forming a part of an oblast or a kray. The Constitution does not regulate the legal consequences of this, but merely states that the legal relations between an autonomous okrug and the oblast or kray which it forms part of can be regulated either through federal law or an agreement between the two federal subjects. Arkhangelsk Oblast and Nenets Autonomous Okrug concluded a preliminary agreement in 1994 and an extended agreement in 1996. These agreements did not solved all questions of formal relations between the two federal subjects, but at least provided a foundation for working relations between the two. ${ }^{30}$

\section{Population and industry in the region ${ }^{31}$}

Murmansk Oblast encompasses the geographic area of the Kola Peninsula, covering a land area of $144,900 \mathrm{~km}^{2}$. Almost all the territory is situated north of the polar circle and the oblast covers two climatic zones - tundra and taiga. During the 1990s, immigration to the oblast slumped and Murmansk, like most other Russian northern regions, experienced a population decline (11.2 per cent from 1990 to 1999). At present, the population is around $1,034,500$. In spite of the recent fall in population, this still makes Murmansk one 
of the most densely populated areas in the entire circumpolar north (7.1 people per $\mathrm{km} 2$ ). The overwhelming majority of the population (92 per cent) is concentrated in the region's widely scattered urban settlements. There are 16 cities in the oblast, the largest being Murmansk with 387,400 inhabitants (down from more than 468,000 at the end of the Soviet period), Apatity $(70,600)$, Monchegorsk $(59,800)$, Severomorsk $(57,100)$ and Kandalaksha $(46,900)$.

Although immigration to Murmansk came from all over the Soviet Union, the oblast is predominantly Russian with ethnic Russians making up 83.8 per cent of the total population. Other ethnic groups living in Murmansk are Ukrainians (8.3 per cent), Belorussians ( 3.5 per cent), Tatars ( 1 per cent), Mordvins ( 0.4 per cent) and Chuvashs ( 0.2 per cent). The aboriginal population, the Saami, today number approximately 1,600 (0.15 per cent of the total population), and are concentrated to the Lovozero Rayon.

The economic geography of Murmansk Oblast is typical of Soviet mono-industrial specialisation. Several of the largest towns in the oblast are dependent on a single or very few enterprises operating in the same type of industry. Table 3.1 shows that the 'dependency rate', defined as the ratio of the number of employees in the largest enterprise in each town to the number of inhabitants, is extremely high in the oblast (more than 20 per cent in all the listed towns).

Table 3.1 Employment by main firm and population in some towns of Murmansk Oblast

\begin{tabular}{lccl}
\hline Town & $\begin{array}{c}\text { Employment in } \\
\text { main company }\end{array}$ & $\begin{array}{c}\text { Population in } \\
\text { municipality }\end{array}$ & Main product \\
\hline Kovdor & $5,000+2,500^{\mathrm{a}}$ & 28,000 & Iron concentrate, apatite \\
Apatity & 18,000 & 82,000 & Apatite concentrate \\
Olenegorsk & 5,500 & 33,800 & Iron concentrate \\
Lovozero & 4,000 & 19,000 & Loparthite \\
Polyarnye Zori & 6,000 & 18,000 & Nuclear power \\
Monchegorsk & 10,000 & 65,500 & Nickel \\
Pechenga & 8,500 & $20,000+$ & Nickel \\
& & $22,000^{\mathrm{b}}$ & \\
\hline
\end{tabular}

Source: Maurseth (1997, 2001).

a two firms.

${ }^{\mathrm{b}}$ population in Nikel and Zapolyarnyy. 
Although the industrial sector of Murmansk Oblast performed better than the Russian average during the economic hardships of the $1990 \mathrm{~s},{ }^{32}$ industrial production decreased significantly during the 1990s, as reflected in Figure 3.4. The figure shows a dramatic reduction in agricultural production and the fishing industry. The fishprocessing plant in Murmansk City used to be one of the largest in Europe, but has operated at a fraction of its full potential since the mid-1990s. The production of raw materials like iron ore and concentrate has decreased less than the overall industrial production. There has even been an increase in the production of apatite. The high concentration of mono-industrial towns in the oblast makes Murmansk particularly vulnerable to economic fluctuations.

Arkhangelsk Oblast - including the archipelagos of Novaya Zemlya and Franz Josef Land, as well as Nenets Autonomous Okrug - covers a territory of $587,400 \mathrm{~km}^{2}$. Even if the okrug is excluded on the basis of constituting a separate federal entity, Arkhangelsk, with a territory of $410,700 \mathrm{~km}^{2}$, remains one of the larger federal

Figure 3.4 Output of some industrial products in Murmansk Oblast in 1998 in \% of 1993 output

\section{(per cent of 1993)}

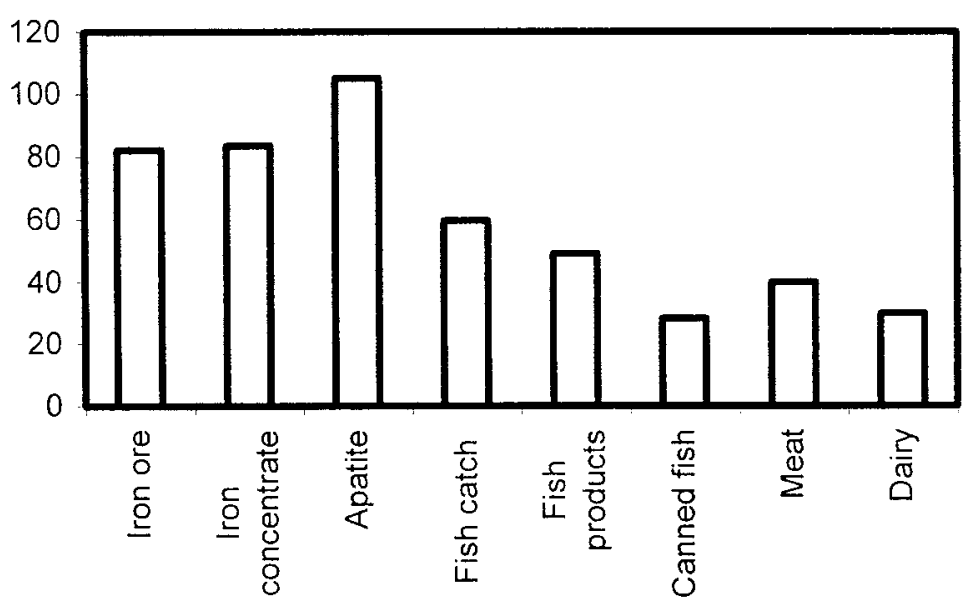

Source: Maurseth (2001) and Murmansk Regional Committee of State Statistics (1999). 
subjects. The present population of the oblast (again excluding the okrug) is 1,491,900 people; 74.1 per cent of the population live in urban settlements. There are fourteen cities, the largest being Arkhangelsk City with 368,900 inhabitants. Other important cities are: Severodvinsk $(239,000$ inhabitans), Kotlas $(66,800)$, Novodvinsk $(48,700)$ and Koryazhma $(44,500) .^{33}$

Arkhangelsk is a thoroughly Russian oblast: 92.1 per cent of the population is ethnic Russian. The largest minority groups are made up by Ukrainians ( 3.4 per cent), Belorussians (1.3 per cent), and Komi (0.5 per cent). Local Russians were traditionally known as Pomors, a subgroup of the Russian ethnos. The Pomors distinguished themselves through their occupation (fishing), traditions, culture and distinct dialect. With the influx of newcomers to the region in the Soviet period, however, the Pomor culture has all but disappeared. The aboriginal population (ancient tribes such as the Chuds and Biarms, as well as the present day Nenets and Saami) have either been assimilated or pushed aside throughout the centuries of Russian domination and no longer compose distinct elements (altogether some 750 Nenets live in the oblast).

Historically, forestry has been the most important industry in the Arkhangelsk region. Until the 1970s, when it was surpassed by Irkutsk Oblast, Arkhangelsk was the leading producer of timber in the Soviet Union. Up to two-fifths of the industrial production is still related to forestry (saw-timber, furniture, paper, pulp etc.). Also shipbuilding has deep roots in Arkhangelsk. The Sevmash and Zvyozdochka shipyards in Severodvinsk serve the military sector (Sevmash builds and Zvyozdochka repairs and modifies nuclear submarines).

Also Arkhangelsk Oblast was hit by the economic crisis of the 1990s. Figure 3.5 demonstrates that, apart from the oil and gas industry mainly located in Nenets Autonomous Okrug, ${ }^{34}$ there was a significant decrease in industrial output in the region. As in Murmansk Oblast, industries serving the domestic consumer market, such as the diary and meat industries, were particularly hard hit. 'Traditional' production of timber and paper nearly halved in the period. The fish-processing industry also experienced a serious decline as a result of lack of raw materials, the local industry unable to compete either in price, or in location in relation to fishing grounds and markets. Arkhangelsk Oblast has a more diversified industrial structure than Murmansk Oblast and is therefore better suited to meet the challenges of further economic hardships. So far, 
Figure 3.5 Output of some industrial products in Arkhangelsk Oblast in 1998 in \% of 1993 output

(per cent of 1993)

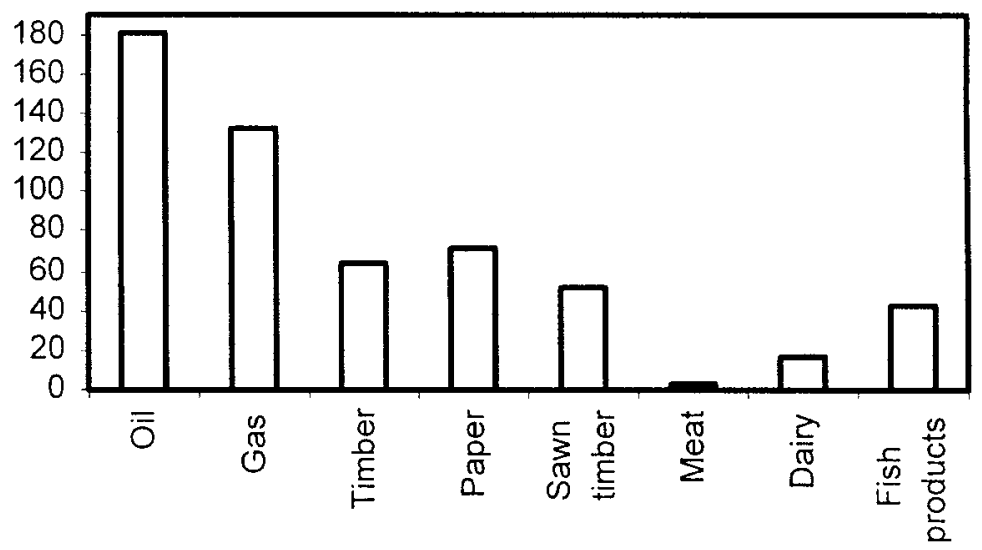

Source: Maurseth (2001) and Arkhangelsk Regional Committee of State Statistics (1999).

however, Arkhangelsk has been heavily dependent on federal transfers. Among the Northwest Russian federal subjects, only Murmansk has been a net donor to the federal budget.

\section{Political organisation of the region}

The regions of the Russian Federation are organised politically according to the same principle as the federal level: a sharing of responsibility between a legislative duma and a directly elected head of the executive power (a president at the federal level as well as in the republics, and governors in the other federal subjects). The latter is not answerable to the former.

The political organisation of Murmansk and Arkhangelsk Oblasts is laid out in their Regional Charters of 26 November 1997 and 23 May 1995, respectively. According to the Charters, the Head of Administration (Governor) is the leading political figure of both regions. The Governor is elected for four years and can only hold the post for two periods. The legislative body of Murmansk Oblast, the regional duma, consists of 25 deputies elected for a four-year 
period. In Arkhangelsk Oblast, there is a regional sobraniye consisting of 41 representatives (including one from Nenets Autonomous Okrug). The Governors have rather wide authority over the regional legislatures inasmuch as they have the right to summon extraordinary sessions of the duma/sobraniye and to reject laws adopted by it. Hence, political power in Northwestern Russia resides for all practical purposes with the Governors and their administration. The Arkhangelsk regional sobraniye is considered as rather co-operative vis-à-vis its regional administration, the Murmansk legislature more hostile (Blakkisrud 2001b, p. 74). In February 1998, a new political structure, the regional government, was introduced in Murmansk Oblast. It is appointed by the Governor and consists of the Deputy Governors, i.e. the leaders of all departments of the regional administration. The First Deputy Governor is appointed premier of the regional government. ${ }^{35}$

Until 1996-97, most governors were appointed by President Yeltsin, among them Yevgeniy Komarov in Murmansk and Pavel Balakshin and later Anatoliy Yefremov ${ }^{36}$ in Arkhangelsk, all recruited from the old party nomenklatura. In the run-up to the gubernatorial elections of Murmansk Oblast in late 1996, Komarov enjoyed substantial economic and moral support from the Kremlin. Prime Minister Chernomyrdin even visited Murmansk on the eve of the elections with the apparent intention of supporting the incumbent. Nevertheless, Komarov did not succeed in bringing victory home. None of the candidates achieved the necessary 50 per cent of the votes in the first round of the elections. In the run-off, Komarov (40.7 per cent) lost to Yuriy Yevdokimov (43.5 per cent), former First Secretary of the Oblast Committee of the Communist Party and former Chairman of the Oblast Soviet (1990-93). Yevdokimov's political platform was the Congress of Russian Communities, the party for which General Aleksandr Lebed had ran in the duma elections in 1995, and his candidacy was supported by Lebed's new Honour and Motherland movement. Yevdokimov has later been associated with the Fatherland movement of Moscow's Mayor Yuriy Luzhkov and threw his support behind Putin after he had been installed as Acting President. ${ }^{37}$ In the following elections in March 2000, Yevdokimov was re-elected with 59.8 per cent of the votes in the first round of elections. He stands forth as an active and entrepreneurial governor who succeeds relatively well in defending the interests of the region vis-à-vis federal authorities. Within the military, he is 
particularly popular for having launched an adoption campaign for the vessels of the Northern Fleet, whereby other federal subjects, cities and business enterprises contribute material supplies to the crisis-ridden fleet. ${ }^{38}$

In Arkhangelsk Oblast, the incumbent succeeded in securing a popular mandate in the 1996 election. Anatoliy Yefremov had been in office for less than nine months and was probably less associated with the negative impact of economic and social reform on the population. Running against the Communist Yuriy Guskov, he could also draw on the entire reform-oriented electorate in the run-off. $\mathrm{He}$ won a solid victory, 62.0 per cent as against Guskov's 28.8 per cent. In the 2000 election, Yefremov won 49 per cent in the first round to former oblast Prime Minister Nikolay Malakov's 32.3 per cent. In the run-off, Yefremov won 58.5 percent of the vote while Malakov got 31.6 per cent.

As follows from the first section of this chapter, bilateral powersharing agreements between Moscow and the federal subjects have become an important instrument in filling the legal vacuum in Russian centre-region relations. Among the Northwest Russian federal subjects, only Murmansk Oblast has concluded a powersharing agreement with federal authorities (Murmansk Oblast 1997a). The agreement was signed by President Yeltsin and Governor Yevdokimov on 30 November 1997. By this time, the process of developing Russian federalism through such agreements was on the wane, and the agreement was not as advantageous to the oblast as the early bilateral agreements of 1994-95. In addition to declarations on co-operation, it lists a range of areas as joint responsibilities, including the environment and management of natural resources. Arkhangelsk began drafting an agreement, but negotiations seem to have stalled. ${ }^{39}$

Federal authorities are heavily represented on the territory of Northwestern Russia. First, some 40-55 federal agencies have their representations in each federal subject of the region. ${ }^{40}$ The Northwestern Federal Okrug, which has its main office in St Petersburg, is also represented. Second, the region is heavily militarised, and as a result large parts of its territory are under federal (military) control. In addition to military base areas, there are six so-called closed towns in Murmansk Oblast - rendering Murmansk the federal subject with most closed towns in the entire Russian Federation and one in Arkhangelsk. These are the direct responsibility of 
federal, not regional authorities. In 1992, a new law, On the Closed Administrative-Territorial Formation (Russian Federation 1992), gave some forty-five formerly secret cities in Russia civilian names and established a division of responsibility between civilian and military authorities within them. A study by the authors of this book (Hønneland and Jørgensen 1998, 1999a) concludes that the closed towns on the Kola Peninsula have not been significantly more integrated into the surrounding civil society since the disintegration of the Soviet Union; politically, economically and socially, the inhabitants and authorities of the closed towns relate more to Moscow and other parts of the Russian Federation than to the regional centre of Murmansk.

Finally, it should be observed that the federal subjects of Northwestern Russia have tended to be less confrontational towards the federal centre than Russian regions in general. They have only to a very limited extent adopted legislation that contradicts federal law, and the elected governors in the area have generally been eager to be on a good footing with the Kremlin. There are several possible explanations for this deference. First, it can be assumed that federal authorities have more control over such a militarised region as Northwestern Russia than less strategically important regions. Second, the abundant natural resources of the region may have made federal authorities particularly eager to maintain control here. Third, it can be argued that the economic vulnerability of the region - Arkhangelsk is a net recipient of the federal budget; Murmansk is a donor, but its industrial future is insecure due to the large concentration of mono-industrial towns here - reduces its leaders' wish to challenge the authority of the federal government. ${ }^{41}$

\section{Conclusions}

The object of study of the present investigation - the implementation of international environmental agreements in Russia - renders the status and application of Article 72 in the Russian Constitution particularly interesting. The management of natural resources and the environment falls under this article and hence under the joint jurisdiction of federal and regional authorities. According to Article 76 of the Constitution, federal law has priority over regional law in areas of joint jurisdiction, but the regional authorities nevertheless enjoy considerable room for manoeuvre. First, federal legislation 
is still poorly developed, and it can become difficult for federal authorities to change a practice that for years has been followed in accordance with regional legislation. Second, there is an almost unlimited number of approaches to an area of law, and Article 76, Paragraph 5, refers only to instances of direct contradiction between legislation of the two levels. In addition to this is the fact that individual bilateral agreements have come to fill the legal vacuum between the federal centre and more than half of the subjects of the Russian Federation.

More interesting for our investigation than the legal peculiarities is the political 'tug-of-war' between various agencies at various levels. A main line of conflict clearly runs between the federal and regional level in general. The former is represented by ministries, state committees, supervisory agencies and others (see above), the latter by the regional administrations under the leadership of governors (in the republics: presidents). We have seen that the governors strengthened their position during the second half of the 1990s, but President Putin in 2000 introduced various measures that may curb their authority. A second line of potential conflict is in the interface between regional authorities and the representations of federal agencies located on their territories. There are indications that representatives of the latter tend to 'go native', becoming primarily spokespersons of their own geographical entity in relation to federal authorities. Third, one can imagine conflicts arising between various agencies at the same administrative level. At the federal level, different ministries or state committees may fight over formal powers since these are normally accompanied by allocations from the federal budget. This is particularly likely in the functional fields of our study since the responsibility to manage natural resources often implies control of revenues from extraction of these resources, and the management of the environment in recent years has come to involve considerable transfers of financial assistance from the West. At the regional level, the number of actors is more limited. A certain degree of conflict is often found between the regional administrations and the regional legislature. However, this has so far not been a major issue in Russian regional politics since the authority of the latter is so limited compared to the regional executive. Finally, the political clout of the former industry complexes - in Soviet times performing both economic activities at enterprise level and the implementation of state politics - and various political bodies at 
both federal and regional level continues to be of interest and will be reverted to in the case studies of the book.

The implementation of international environmental agreements in Northwestern Russia takes place in a political and administrative setting that is still in the making, and in an atmosphere of economic insecurity. Both Murmansk and Arkhangelsk Oblasts have been hard hit by the general economic crisis in Russia during the 1990s. Production has fallen markedly in most sectors of the economy; the result is increased unemployment and decreased population in the region. Prospects for the future are particularly insecure for the mono-industrial towns of Murmansk Oblast. Nevertheless, Murmansk is so far the only federal subject in Northwestern Russia that is a net donor to the federal budget.

The federal subjects of Northwestern Russia have generally sought a co-operative, rather than a confrontational stance in relation to federal authorities. This preliminary 'conclusion' will be further tested in the sector analyses of this book: first, have regional authorities given federal agencies the upper hand also in matters of fisheries management, nuclear safety and air pollution control? Second, how are power relations between regional authorities and representations of federal authorities in the regions? Little is known about the relations between these two categories of government in Northwestern Russia in general. The issue to be raised in the case studies of the book is whether they tend to side with each other or represent competing positions. For instance, do regional agencies of the federal system for fisheries management mainly defend the interests of the regional fisheries complex? Third, are there conflicts between different agencies at the same administrative level? The governors and their regional administrations are by far the most important political figures in Northwestern Russia, but do the regional legislatures nevertheless have a certain influence in environmental matters? Finally, how is the role of the former 'industry complexes' to be understood? This last question is highly relevant for all three case studies. Is the old concept of the "northern fishery basin' - previously gathered under the Sevryba umbrella - still a relevant category in discussions about Northwest Russian fisheries management? What is the role of the 'nuclear complex' - mainly understood as the power plant at Polyarnye Zori, the nuclear icebreaker fleet of Murmansk Shipping Company and the military nuclear installations - in securing nuclear safety in the region? Is the 
mining and metallurgical complex a significant actor in issues of air pollution control? And how has the representation of industrycomplex' directors in the regional duma of Murmansk Oblast affected regional legislation?

\section{Notes}

1 This and the next section are partly adapted from Hønneland and Jørgensen (1999a), which in turn was based on Blakkisrud (1997).

2 The Russian empire was organised in gubernii which were ruled by governors and directly subordinate o the cabinet in St Petersburg. With a few exceptions, their borders were not drawn in accordance with ethno-demographic realities.

3 The first federal unity within the RSFSR, the Volga-German Autonomous Workers' Commune, was established in October 1918, but it was only after the end of the Civil War that the federalisation process gathered momentum.

4 Since their unity was maintained through power at the centre, some observers have described them as pseudo-federations (Duchacek 1987).

5 There was arguably a fourth hierarchy, that of the central ministries whose enterprises (each with its own party cell) operated independently of the Soviets and the executive committees, see Whitefield (1993).

6 Among other things, they included a proposal to dissolve the ethnically defined entities and create fewer and larger territorially defined federal subjects. See Hanson (1994) and Sakwa (1993) for a discussion.

7 The Jewish Autonomous Oblast (Birobidzhan) was the only autonomous oblast not to gain the status of republic. It was, however, recognised as an independent federal subject separate from the kray of Khabarovsk, to which it had previously been subordinate.

8 The designations sobraniye (assembly) and soviet (council) could also be used.

9 This section is based on Risnes (2001).

10 A striking example is the regulation of ownership of land. The federal authorities were working on drafts of a land code for a number of years, but succeeded in passing a final code only in autumn 2001. The reason for this delay was disagreement between the President and the state duma. In the meantime, more than fifty federal subjects had adopted their own land codes.

11 There were twenty-four ministries until October 2001, when the Ministry of Federation Affairs, Nationalities and Migration Policies was disbanded. However, in December the same year a new minister without portfolio was appointed to co-ordinate government institutions on 
nationalities issues (RFE/RL Russian Federation Report, 6 December 2001).

12 A system of presidential representatives in the oblasts and krays was first introduced immediately after the coup attempt in August 1991. Later, it was extended to the republics, and eventually institutionalised in the 1993 Constitution. Such representatives were not sent to all federal subjects. Generally, Yeltsin seemed more reluctant to station his representatives in ethnically defined than in territorially defined federal subjects.

13 This section is based partly on Blakkisrud (2001b).

14 A famous statement representing this development is Boris Yeltsin's, then newly elected Chairman of the Supreme Soviet of the RSFSR, invitation to the autonomous areas of the Union to 'take as much sovereignty as you can swallow'.

15 Several regional elections were actually held, where heads of administration were replaced by representatives of the local elite. See Hanson (1994) for details.

16 However, the picture is not unambiguous. In general, leaders of the ethnically defined federal subjects were elected, and they also tended to escape the interference of presidential representatives.

17 This section is based on Maurseth (2001).

18 During the first years of the existence of the Russian Federation, there were signs of regional authorities providing services that were obviously a federal responsibility, like issuing 'surrogate money'. This seems to have become less widespread in recent years.

19 The VAT rate was 20 per cent in 2000 , tax on profit 30 per cent and tax on personal income 13 per cent.

20 The Federal Fund for Financial Support of the Regions was set up in 1994 to create a more coherent framework for channelling resources to the most needy regions. The fund, partly financed by VAT receipts, still constitutes the major source for federal transfers to the regions.

21 Referred in Maurseth (2001).

22 Keeping the rouble within the predetermined 'rouble corridor' was viewed as essential to deflate the economy. This had been achieved since 1995, and the economic growth since 1997 was regarded as a well-deserved result of this monetary stabilisation.

23 These terms are mainly used for statistical purposes.

24 All of Russia's 89 federal subjects except for Chechnya belong to one of eight inter-regional economic associations set up between 1992 and 1994, and based on Soviet-era economic-administrative divisions (i.e. planning regions). The ambitions and work practices differ somewhat among the associations, but their common goal is to co-ordinate internal co-operation as well as their relations with the political centre. The 
Siberian Accord is often referred to as the most ambitious, extensive and successful of the inter-regional associations.

25 For the sake of language variation, the geographical terms are sometimes used without indication of federation subject category (oblast, republic or okrug). This might serve to confuse the two oblasts of the region with the cities of similar names. However, the cities are always referred to specifically, e.g. as Murmansk City or the city of Arkhangelsk.

26 The presentation is based on Hønneland and Jørgensen (1999a) and Blakkisrud and Hønneland (2001). Statistical material is from Makfol and Petrov (1998) and Goskomstat Rossii (1998).

27 The Terskiy Coast (the eastern part of the peninsula) came under the control of the Republic of Novgorod in the thirteenth century, but there are no records of permanent Novgorodian settlement on the peninsula until the first half of the fifteenth century. Following the collapse of the Novgorodian state in 1487, the area became a relatively neglected northern outpost of the Muscovite Principality. Almost a century later, permanent settlements were established along the northern coast at Kola and Pechenga, the first centred around a new fortification, the latter around a monastery. In 1708, Kola Uyezd (district) was included in the new Arkhangelsk Guberniya. In 1883, however, the uyezd was re-established within the guberniya and subsequently renamed Aleksandrovsk Uyezd in 1899 after the newly founded town of Aleksandrovsk (the present closed military town of Polyarnyy).

28 The new oblast consisted of the territory of the former Murmansk Okrug, as well as Kandalaksha Rayon, which was transferred from Karelia. In 1945, the former Finnish territory of Petsamo (now Pechenga) and the port of Liinakhamari were transferred to the oblast.

29 During most of the Soviet period known as the Kirov Railway.

30 See Blakkirud (2001a, 2001b) and Risnes (2001) for discussions of the relationship between Arkhangelsk Oblast and Nenets Autonomous Okrug.

31 This section is based on Hønneland and Jørgensen (1999a), Hønneland and Blakkisrud (2001) and Maurseth (2001).

32 At the turn of the millennium, the industrial production of the oblast had stabilised at 65 per cent of the 1991 level as compared to 50 per cent for Russia as a whole. The corresponding figure for Arkhangelsk Oblast was 61 per cent.

33 These cities make up two clusters of urban settlements: Severodvinsk, which is a centre for the military-industrial complex and the shipbuilding industry, and Novodvinsk with its wood-processing industry are satellites of Arkhangelsk, whereas Koryazhma is a satellite of Kotlas, the centre of the southern, agricultural region. On the other hand, Novaya Zemlya and Frantz Josef Land as well as the northern parts of the mainland are more or less uninhabited. 
34 As seen in Figure 3.5, the production of oil and gas enjoyed a considerable increase in the period. Since energy prices were extremely low in the Soviet Union as compared to world market prices, the Russian integration into the world economy boosted the price of oil and gas dramatically, hence increasing profits and thereby also production of oil and gas.

35 The introduction of this new institution seems to have had very limited consequences.

36 Balakshin was removed from office in February 1996, allegedly due to economic mismanagement.

37 Hedenskog (2000) points out that Yevdokimov displays an astonishing proclivity to play on the wrong horse among the top politicians in Russia: as leader of the regional Soviet in 1993, he supported Vice President Aleksandr Rutskoy and Chairman of the Supreme Soviet Ruslan Khasbulatov in their struggle with President Yeltsin. Later, he supported Sergey Kiriyenko in August 1998 and Yevgeniy Primakov in April 1999, at times when both prime ministers were on the threshold of being removed from power.

38 When asked in a television interview in October 1999 what had been his most important achievement as a politician, Yevdokimov referred to this adoption campaign. For more detailed descriptions of the campaign, see Hønneland and Jørgensen (1999a) or Jørgensen (2001).

39 See Blakkisrud (2001b) and Risnes (2001) for differing views on the prospects of Arkhangelsk Oblast eventually concluding a powersharing agreement with federal authorities.

40 The exact figure varies. In late 1999, the number for Murmansk was 40 and for Arkhangelsk 54 (Blakkisrud 2001; Risnes 2001). No investigation has been carried out of the degree to which these have 'gone native' (see first section of this chapter). This question will partly be addressed in the case studies of this book.

41 Relations between Moscow and the federal subjects of Northwestern Russia are discussed at length in Hønneland and Blakkisrud (2001). 